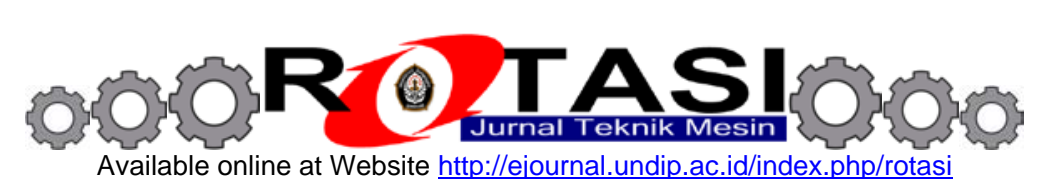

\title{
Kaji Numerik Aliran Jet-Swirling Pada Saluran Annulus Menggunakan Metode Volume Hingga
}

\author{
Nazaruddin Sinaga \\ Departemen Teknik Mesin, Fakultas Teknik, Universitas Diponegoro \\ Jalan Prof. Soedharto, SH, Tembalang, Semarang 50275, Telpon +62247460059 \\ E-mail: nazarsinaga@undip.ac.id
}

\begin{abstract}
Abstrak
Pada saat ini proses pembakaran dituntut lebih efisien dengan emisi gas buang yang lebih bersih. Salah satu teknik yang dapat diterapkan adalah menggunakan aliran swirling, baik sebelum maupun di dalam ruang bakar. Pada penelitian ini dikaji tentang kemampuan metoda komputasi numerik, menggunakan metoda volume hingga dengan bantuan paket program FLUENT, untuk memprediksi efek bilangan swirling terhadap intensitas turbulensi serta kecepatan aksial dan tangensial di dalam saluran berbentuk annulus. Hasil perhitungan divalidasi dengan hasil yang telah dilakukan oleh peneliti sebelumnya. Selanjutnya dilakukan simulasi pengaruh bilangan swirling terhadap ketiga parameter tersebut, yaitu dengan nilai $\mathrm{S}=0 ; 0,4 ; 0,7 ; 1$ dan 1,2 . Pada penelitian ini model geometri yang digunakan adalah sama dengan geometri pada literatur. Fluida yang digunakan yaitu campuran n-Oktan $\left(\mathrm{C}_{8} \mathrm{H}_{18}\right)$ dan udara, pada kecepatan masuk konstan 25,5 m/s . Model turbulensi yang digunakan dalam perhitungan ini adalah k- $\varepsilon$ standar. Dari penelitian ini disimpulkan bahwa hasil perhitungan yang dilakukan memberikan hasil yang cukup valid dibandingkan dengan hasil literatur. Selanjutnya dihasilkan bahwa dengan meningkatnya bilangan swirl maka akan meningkatkan intensitas turbulensi dan kecepatan tangensial secara signifikan, sehingga akan meningkatkan efek pencampuran. Hasil penelitian ini tentunya sangat bermanfaat digunakan dalam merancang saluran dan ruang bakar.
\end{abstract}

Kata kunci: annulus, intensitas turbulensi, metoda numerik, swirling, volume hingga

\section{Pendahuluan}

Kebutuhan terhadap proses pembakaran yang sempurna merupakan kajian yang menarik untuk dibicarakan dan dikembangkan. Hal ini karena semakin berkembangnya pengetahuan tentang sistem pembakaran serta makin banyaknya parameter prestasi yang diketahui mempengaruhi prestasi pembakaran. Begitu juga dengan analisa aliran fluida pada saluran masuk sebelum proses pembakaran dengan berbagai macam bentuk geometri yang berbeda sudah banyak dilakukan, diantaranya dengan metoda teoritk dan eksperimental. Jika geometri sistem yang dianalisa tidak sederhana, maka cara teoritik akan menemui kesukaran dalam menyelesaikannya. Untuk mengatasi kendala tersebut maka metoda numerik merupakan salah satu solusi alternatif dalam analisis dinamika aliran. Methode komputasi numerik dipercaya dapat memprediksi sesuatu dengan lebih cepat dan mudah serta biaya yang relatif lebih kecil dibandingkan dengan metoda eksperimental. Disamping itu metoda numerik juga dapat mengatasi kendala geometri yang rumit dan syaratsyarat batas yang merupakan penghambat metoda analitik.

Kajian aliran swirling sudah cukup banyak dipelajari, baik secara ekperimental maupun secara numerik. Hal ini karena aliran swirling ini cukup banyak pemanfaatannya dalam aplikasi teknik, diantaranya untuk pemanfaatan dalam analisis dan perancangan sistem pembakaran. Mekanisme aliran ini dapat meningkatkan homogenitas pencampuran bahan bakar dengan udara, meningkatkan kualitas pembakaran karena meningkatnya kualitas pencampuran bahan bakar dan udara akibat meningkatnya intensitas turbulensi dan kecepatan tangensialalran. Hal inilah yang melatar belakangi penulis tertarik untuk mengkaji lebih jauh efek aliran swirling jet dalam saluran lurus menggunakan annulus untuk meningkatkan pencampuran (mixing) bahan bakar n-octane $\left(\mathrm{C}_{8} \mathrm{H}_{18}\right)$ dan udara.

\section{Dasar teori}

\subsection{Aliran laminar melalui annulus berpenampang lingkaran}

Aliran yang terjadi melalui annulus adalah aliran fluida yang dibatasi oleh permukaan padat yaitu diantara dua pipa konsentris dengan radius $r_{1}$ (radius pipa annulus) dan $r_{2}$ (radius pipa luar). Aliran melalui annulus ini mirip dengan aliran di dalam pipa, perbedaannya terletak pada sebuah annulus atau pipa pejal yang diletakkan di tengah-tengah sumbu sebuah pipa dengan diameter yang lebih besar dibandingkan diameter annulus itu sendiri (lihat Gambar 1). Aliran melalui annulus dengan luas permukaan konstan dikatakan fully developed jika bentuk profil kecepatannya sama pada berbagai penampang [1]. Aliran fully developed mudah dianalisis karena satu dimensio, dimana kecepatan bervariasi hanya terhadap jarak pipa dari sumbu pipa. 


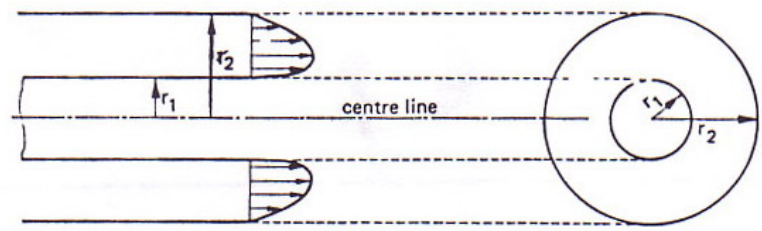

Gambar 1. Aliran laminar inkompresibel di dalam anulus [2]

\subsection{Aliran Swirling}

Penerapan aliran swirling banyak digunakan dalam bidang teknik, seperti dalam sistem pembakaran turbin gas, motor bakar, cyclone, burner industri, boiler dan lain-lain. Pada sistem pembakaran turbin gas digunakan dengan tujuan untuk meningkatkan efisiensi pencampuran bahan bakar dengan udara, meningkatkan intensitas pembakaran dan menstabilkan nyala api, dengan memanfaatkan zona yang masih dipengaruhi putaran (internal recirculation zone) [3]. Gerakan swirling pada saluran inlet biasanya dihasilkan dengan menggunakan pengarah (vane guide), inlet tangential flow injection, rotating pipe (pipa rotasi) ataupun dengan generator swirler lainnya seperti ditunjukkan pada Gambar 2.
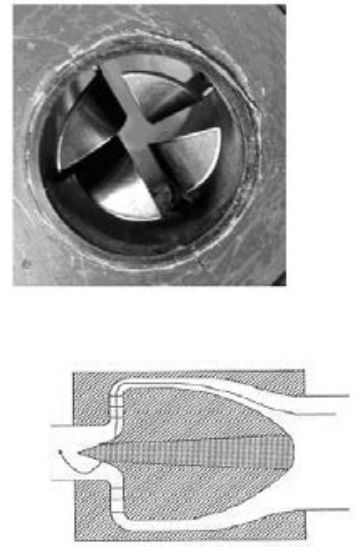

c) a)
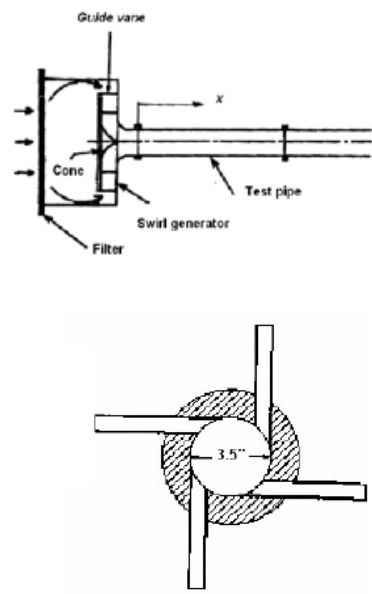

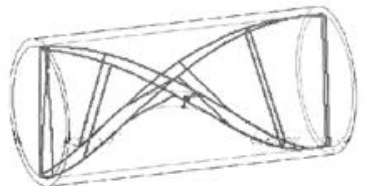

b)

d)

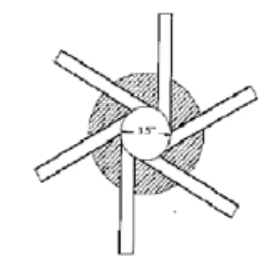

Gambar 2. Beberapa macam generator swirl: (a) Fixed vanes, (b) Twisted tape,

(c) Propeller type, (d) Tangential injection [4]

Komponen kecepatan koordinat silinder pada 3D, 2D dan domain aksi-simetri serta arah kecepatan untuk masing-masing kecepatan ditunjukkan dalam Gambar 3. Dalam koordinat tersebut, kecepatan swirl adalah ekivalen dengan kecepatan arah tangensial, yaitu kecepatan yang berputar arah tangensial dalam sistem koordinat silinder.


Gambar 3. Komponen kecepatan silindris pada domain aksisimetri 2D dan 3D [5]

Parameter bilangan swirl, S, dinyatakan dengan persamaan berikut [6] :

$\mathrm{S}=\left(\int_{0}^{R} \rho u w r^{2} d r\right) /\left(R \int_{0}^{R} \rho u^{2} r d r\right)$

dimana u dan w adalah kecepatan axial dan kecepatan azimuthal, $\mathrm{r}$ adalah radius/jarak, $\rho$ adalah densitas fluida, $\mathrm{R}$ dan adalah radius outlet jet. Bilangan swirl S didefinisikan sebagai rasio flux momentum angular dengan flux momentum 
axial. Bilangan S dalam simulasi ini diberikan pada saat mendefinisikan kondisi batas pada sisi inlet. Dalam penelitian ini bilangan swirl ditetapkan dengan nilai $0 ; 0,4 ; 0,7 ; 1$ dan 1,2 .

\subsection{Intesitas turbulent}

Intensitas turbulent $I$ didefinisikan sebagai rasio antara kecepatan fluktuasi dengan kecepatan aliran rata-rata, dan dinyatakan dengan persamaan berikut :

$I=\frac{\left(u^{\prime}\right)^{2}}{u_{a v g}}$

Pada aliran swirling, dimana alirannya memuat komponen kecepatan tangensial (azimuthal) dengan nilai $V_{t} \neq 0$, sering dikaitkan pengaruhnya dengan peningkatan kecepatan fluktuasi kecepatan u' [4]. Sehingga dengan adanya kecepatan ini akan meningkatkan intensitas turbulensi sebagai akibat dari peningkatan fluktuasi kecepatan u'.

\section{Metoda perhitungan numerik}

\subsection{Computational Fluid Dynamic (CFD)}

Selain pengujian terowongan angin atau yang sering disebut dengan Eksperimental Fluid Dynamics (EFD), Computational Fluid Dynamics (CFD) adalah suatu metoda yang dapat digunakan untuk menyelesaikan masalah aliran fluida, perpindahan panas dan fenomena yang terkait dengan reaksi kimia, dengan menggunakan perangkat lunak pada komputer. FLUENT merupakan paket program komputer yang ditulis dalam bahasa pemrograman C untuk memodelkan aliran fluida dan perpindahan panas dalam geometri yang kompleks [5]. Piranti lunak ini memberikan fleksibilitas mesh yang lengkap, memecahkan masalah aliran dengan mesh yang tidak terstruktur, yang dapat dihasilkan dengan cara yang relatif mudah pada geometri yang kompleks. Piranti ini juga dapat memperhalus atau memperkasar grid (adapsi grid) berdasarkan solusi aliran yang dihasilkan. Kemampuan adapsi grid ini berguna untuk memprediksi medan aliran dalam daerah dengan gradien yang besar, seperti lapisan geser bebas dan lapisan batas. Paket program ini juga dilengkapi dengan aplikasi penunjang untuk menggambar geometri dan generasi mesh.

\subsection{Proses simulasi}

\subsubsection{Deskripsi masalah}

Simulasi ini dibatasi pada model sebuah saluran lurus berdiameter D dengan sebuah annulus berdiameter d, yang memiliki outlet berupa aliran jet. Model aliran seperti ini banyak dipelajari dalam mekanika fluida, misalnya dalam mempelajari sistem pembakaraan bahan bakar. Domain geometri dan kondisi batas yang digunakan dalam simulasi ini ditunjukkan pada Gambar 4, sedangkan pada Tabel 1 diperlihatkan dimensinya. Pada simulasi ini sebuah silinder pejal tunggal berdiameter $\mathrm{d}=50 \mathrm{~mm}$ ditempatkan dalam saluran lurus yang didalamnya mengalir fluida campuran n-octana dan udara, dengan aliran yang diasumsikan fully developed.
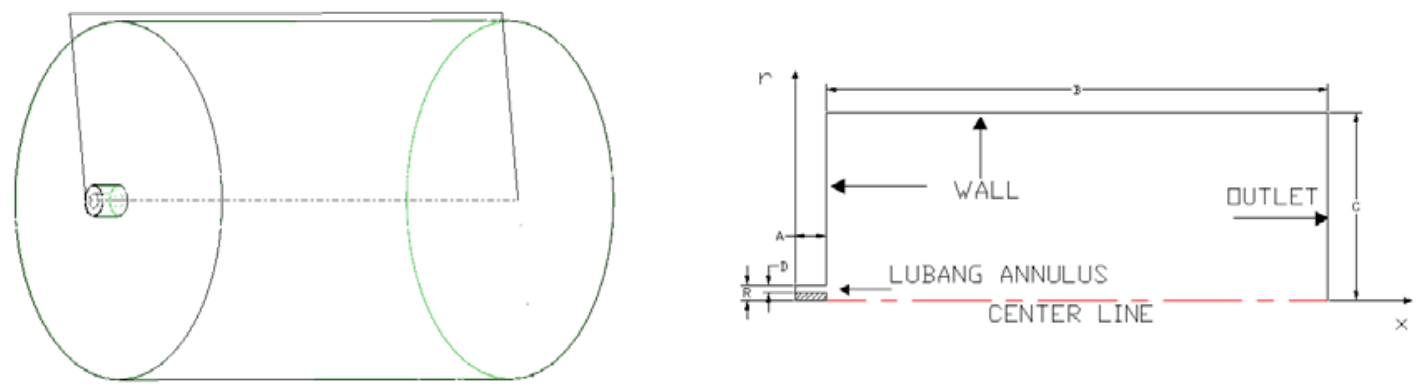

Gambar 4. Domain geometri dan kondisi batas sistem annulus

Tabel 1. Parameter Geometri

\begin{tabular}{|l|c|}
\hline \multicolumn{1}{|c|}{ Parameter } & Range Modeled \\
\hline A: panjang annulus & $100 \mathrm{~mm}$ \\
\hline B: panjang jet outlet & $1600 \mathrm{~mm}$ \\
\hline C: lebar jet outlet & $600 \mathrm{~mm}$ \\
\hline D: lebar saluran annulus & $25 \mathrm{~mm}$ \\
\hline R: radius jet outlet & $50 \mathrm{~mm}$ \\
\hline
\end{tabular}

\subsubsection{Sifat fluida dan aliran}

Bilangan Reynold (Re) dihitung berdasarkan panjang saluran, L, dimana $L=2\left(r_{2}-r_{1}\right)$ dan kecepatan aliran V. Dalam simulasi ini bilangan Reynold ditetapkan berdasarkan data yang diperoleh dari jurnal yang digunakan sebagai acuan untuk memvalidasinya, yaitu $\operatorname{Re}=81500$. 
$\operatorname{Re}=\frac{\rho V L}{\mu}=\frac{V L}{v}$

Sifat-sifat fluida yang digunakan adalah konstan dengan nilai sebagai berikut:

- V = Kecepatan fluida masuk $=25,5 \mathrm{~m} / \mathrm{s}$

- $\mu$ = viskositas absolut fluida $=1,9035.10^{-5} \mathrm{~kg} / \mathrm{m}-\mathrm{s}$

- $\mathrm{cp}=$ panas jenis pada tekanan konstan $=1039,2 \mathrm{~J} / \mathrm{Kg} \cdot \mathrm{K}$

- $\mathrm{k}=$ konduktivitas termal $=0.024425 \mathrm{~W} / \mathrm{m} . \mathrm{K}$

- $\sigma=$ difusivitas massa $=1.5648 .10^{-5} \mathrm{~m}^{2} / \mathrm{s}$

\subsubsection{Simulasi Fluent}

Simulasi awal ini didasarkan pada original mesh. Adapun jumlah sel dan nodalnya diperlihatkan pada Tabel 2.

Model solusi yang digunakan dalam perhitungan menggunakanan metode solusi seperti ditunjukkan pada Tabel 3.

Tebel 2. Jumlah sel, grid dan nodal

\begin{tabular}{|c|c|c|}
\hline Jumlah sel (cells) & Jumlah face & Jumlah nodal (Nodes) \\
\hline 226200 & 453.400 & 227.201 \\
\hline
\end{tabular}

Tabel 3. Model solusi yang digunakan

\begin{tabular}{|l|l|}
\hline Solver & Segregated \\
\hline Space & Axisimmetric Swirl \\
\hline Calculation Method & Steady \\
\hline Viscous Model & $k$ - Standard \\
\hline Near Wall Treatment & Standard Wall Function \\
\hline Discretization: Pressure & Standard \\
\hline
\end{tabular}

\subsubsection{Proses Adapsi}

Proses adapsi grid dilakukan dengan memanfaatkan fasilitas yang disediakan oleh FLUENT. Tujuan dari proses ini adalah untuk mendapatkan grid independen, dimana hasil simulasi tidak tergantung dari jumlah grid. Seluruh proses adapsi dalam simulasi ini dilakukan dengan cara memperhalus sel-sel yang dekat annulus, inlet, inlet dan outlet. Pada Tabel 4 ditunjukkan jumlah grid yang dihasilkan dari setiap proses adapsi.

Tabel 4. Jumlah grid hasil proses adapsi

\begin{tabular}{|c|c|c|c|}
\hline Proses adapsi & Jumlah sel & Jumlah muka & Jumlah nodal \\
\hline original & 226.200 & 453.400 & 227.201 \\
\hline 1 & 229.263 & 460.550 & 231.288 \\
\hline 5 & 241.395 & 484.814 & 243.420 \\
\hline 10 & 256.290 & 514.604 & 258.315 \\
\hline 15 & 270.738 & 543.489 & 272.752 \\
\hline 20 & 284.853 & 571.719 & 286.867 \\
\hline
\end{tabular}

\subsubsection{Validasi hasil simulasi}

Dari hasil simulasi yang dilakukan terhadap kasus pada literatur [6] yang digunakan sebagai bahan untuk memvalidasi, maka didapatkan perbandingan antara hasil simulasi dan hasil yang ada pada literatur tersebut, dengan memvariasikan nilai bilangan swirling, $\mathrm{S}$.

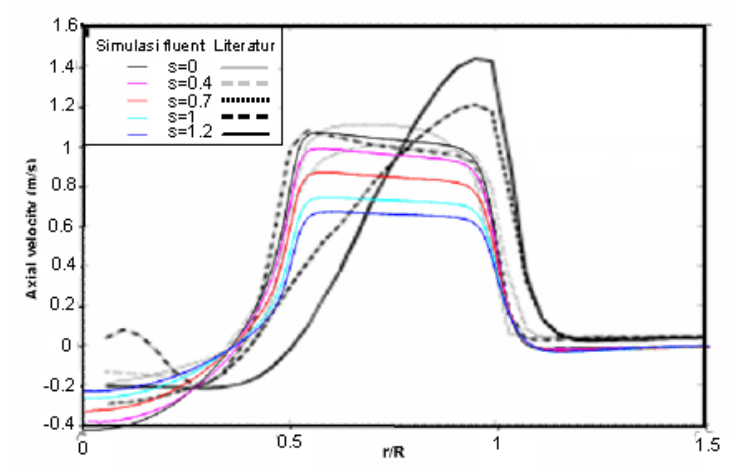

Gambar 5. Perbandingan hasil simulasi dan literatur

Pada Gambar 5 diperlihatkan perbandingan kecepatan axial pada $\mathrm{x}=0,11 \mathrm{~m}$ antara hasil simulasi yang dilakukan, dengan menggunakan model turbulensi k- $\varepsilon$ standar, dengan hasil literatur yang menerapkan model Large 
Eddy Simulation (LES) yang dilakukan oleh M. Garcia Villalba dan J. Frochlich [6]. Dari gambar tersebut terlihat perbedaan yang cukup besar pada hasil simulasi untuk bilangan $S=1$ dan $S=1,2$. Perbedaan besar terlihat pada kecepatan axial di daerah wake, namun setelah daerah tersebut untuk semua nilai S memperlihatkan adanya kecenderungan kesamaan profil kecepatan. Perbedaan yang tidak begitu besar diperlihatkan pada simulasi dengan nilai $\mathrm{S}=0$ dan $\mathrm{S}=0,4$ yang hampir memiliki profil kecepatan sama. Hasil simulasi ini secara umum dianggap masih kuran memuaskan, sehingga perlu dilakukan langkah-langkah penghalusan grid dengan melakukan proses adapsi.

Gambar 6 memperlihatkan perbandingan kecepatan axial dari proses adapsi yang dilakukan pada simulasi dengan bilangan $S=1,2$ dan posisi $x=0,11$. Dari gambar tersebut terlihat bahwa hasil simulasi pada variasi adapsi yang dilakukan menunjukkan hasil yang mirip. Hasil yang agak berbeda ditunjukkan pada daerah wake yaitu di dekat annulus dan sumbu (centerline), seperti ditunjukkan pada Gambar 7. Namun secara keseluruhan simulasi menunjukkan kecenderungan kesamaan profil kecepatan. Dari gambar tersebut dapat disimpulkan bahwa hasil simulasi yang dilakukan memenuhi syarat grid independen, yaitu hasil simulasi yang tidak tergantung dari jumlah grid. Berikut ini adalah beberapa perhitungan tingkat penyimpangan relatif (relative error) yang dilakukan pada beberapa daerah/segmen yang diamati secara acak untuk data-data hasil simulasi kecepatan axial, mass flow dan intensitas turbulensi. Perhitungan tingkat penyimpangan relatif (relative error) dilakukan dengan persamaan sebagai berikut:

$$
R E=\text { Relative Error }=\left|\frac{X_{n}-X_{\text {non-adapsi }}}{X_{\text {non-adapsi }}}\right| \times 100 \%
$$

dimana:

$\mathrm{X}_{\mathrm{n}}$

$\mathrm{X}_{\text {non-adapsi }}$

$=$ data hasil simulasi adapsi ke-n

= data hasil simulasi tanpa dilakukan proses adapsi

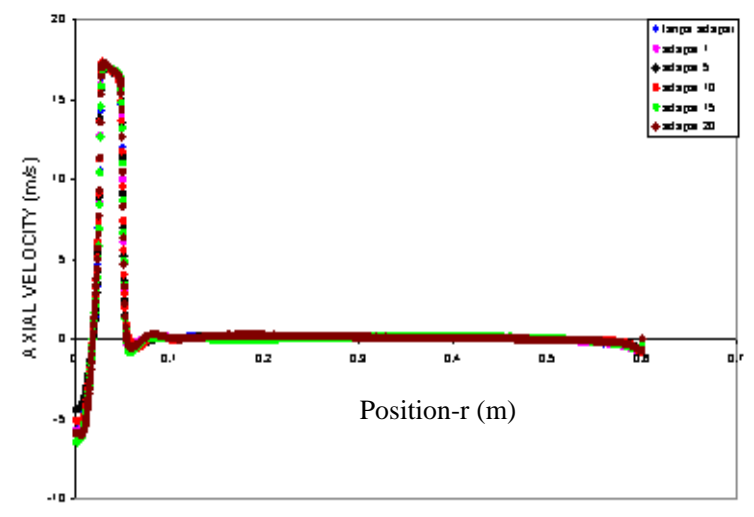

Gambar 7. Perbandingan kecepatan axial hasil adapsi

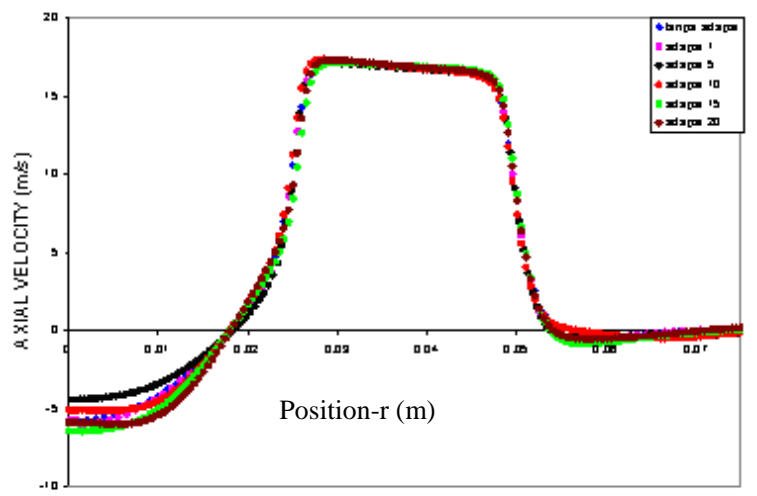

Gambar 6. Kecepatan axial di daerah wake

Pada Tabel 5 diperlihatkan nilai penyimpangan relatif (RE) untuk kecepatan aksial, laju aliran massa (mass flow) dan intensitas turbulensi dari berbagai tingkat adapsi yang dilakukan. Dari hasil perhitungan penyimpangan relatif kecepatan axial rata-rata yang dilakukan dalam simulasi diperoleh hasil dimana untuk segmen $\mathrm{x}=0,11$ tingkat penyimpangan terbesar terjadi pada adapsi-1 sebesar 2,55 \%, sedangkan untuk segmen $\mathrm{x}=0,25$ tingkat penyimpangan terbesar terjadi pada adapsi-10 dan 20 sebesar 0,10 \%. Dari hasil perhitungan tingkat penyimpangan relatif mass flow yang dilakukan dalam simulasi diperoleh hasil untuk segmen $\mathrm{x}=0,25$ tingkat penyimpangan terbesar terjadi pada adapsi-20 sebesar 15,59 \% sedangkan untuk segmen $\mathrm{x}=1,5$ tingkat penyimpangan terbesar terjadi pada adapsi-15 sebesar $17.99 \%$. Begitu pula dengan nilai penyimpangan intensitas turbulensi yang relatif kecil. Hasil ini memperlihatkan bahwa tingkat penyimpangan relatif dari simulasi yang dilakukan adalah sangat kecil, sehingga dapat disimpulkan bahwa hasil simulasi yang dilakukan Position-r(m) a grid independen, yaitu hasil simulasi tidak tergantung dari jumlah grid yang digunakan.

Tabel 5. Prosentase Relatif Error (RE) hasil simulasi terhadap proses adapsi

\begin{tabular}{|c|c|c|c|c|c|c|}
\hline Adapsi & $\begin{array}{c}\text { RE Kec. Axial } \\
\text { pada } x=0,11\end{array}$ & $\begin{array}{c}\text { RE Kec. Axial } \\
\text { pada } x=0,25\end{array}$ & $\begin{array}{c}\text { RE Mas Flow } \\
\text { pada } x=0,11\end{array}$ & $\begin{array}{c}\text { RE Mas Flow } \\
\text { pada } x=0,25\end{array}$ & $\begin{array}{c}\text { RE Intensitas Turbulen } \\
\text { pada } x=0,11\end{array}$ & $\begin{array}{c}\text { RE Intensitas Turbulen } \\
\text { pada } x=0,25\end{array}$ \\
\hline No adapsi & 0 & 0 & 0 & 0 & 0 & 0 \\
\hline Adapsi-1 & 2,55 & 0,04 & 2,55 & 0,04 & 0,40 & 0,57 \\
\hline Adapsi-5 & 0,73 & 0,01 & 0,73 & 0,01 & 0,86 & 1,76 \\
\hline Adapsi-10 & 0,69 & 0,10 & 0,69 & 0,10 & 5,47 & 4,36 \\
\hline Adapsi-15 & 0,62 & 0,02 & 0,63 & 0,01 & 11,89 & 17,99 \\
\hline Adapsi-20 & 0,65 & 0,10 & 0,65 & 0,10 & 15,59 & 9,83 \\
\hline
\end{tabular}




\section{Analisa hasil simulasi}

\subsection{Kontur kecepatan axial pada variasi bilangan swirl s}

Dari Gambar 8 dapat diamati bahwa pada bilangan S yang lebih kecil memiliki sebaran kecepatan axial maksimum yang lebih tinggi dan luas pada daerah dekat inlet annulus. Dengan S yang makin besar, pada daerah sekitar centerline terjadi perluasan zona dimana kecepatan axialnya minimum. Untuk $\mathrm{S}=1,2$ memiliki kecepatan axial yang relatif terkecil dibanding yang lainnya. Hal ini terjadi karena untuk simulasi dengan bilangan swirling 1,2 komponen input kecepatan terbesarnya adalah aliran swirl atau kecepatan tangensial.
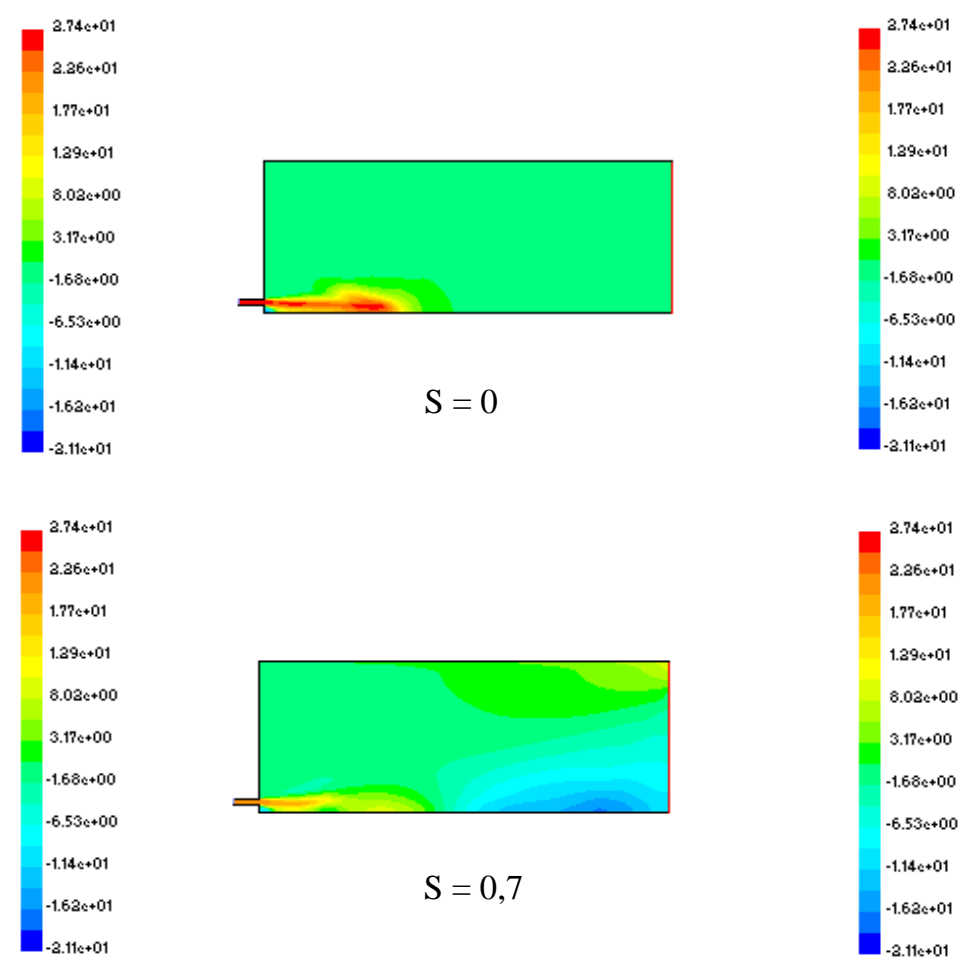



$\mathrm{S}=0,4$

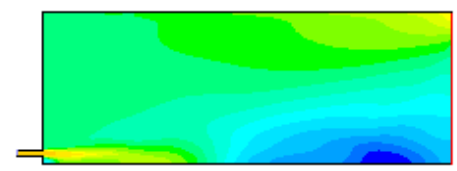

$\mathrm{S}=1,2$

Gambar 8. Kontur kecepatan axial pada variasi bilangan swirl

\subsection{Kecepatan axial lokal pada variasi bilangan swirl s}

Pada Tabel 6 dapat dilihat bahwa penerapan bilangan swirl S yang makin besar menyebabkan penurunan kecepatan axial rata-rata pada setiap segmen yang diamati. Sehingga dari simulasi yang dilakukan, kecepatan rata-rata terbesar terjadi pada simulasi $\mathrm{S}=0$. Adapun pada Tabel 7 ditunjukkan lokasi segmen yang diamati untuk mengetahui nilai kecepatan axial rata-rata tersebut.

Tabel 6. Posisi kecepatan axial maksimum

\begin{tabular}{|c|c|c|c|}
\hline Posisi x (m) & $\begin{array}{c}\text { Kecepatan Maximum } \\
(\mathrm{m} / \mathrm{s})\end{array}$ & $\begin{array}{c}\text { Posisi } \mathrm{r} \\
(\mathrm{m})\end{array}$ & Bilangan S \\
\hline 0,11 & 27,35 & 0,029 & 0 \\
\hline 0,25 & 25,37 & 0,0285 & 0 \\
\hline 0,5 & 26,31 & 0,0205 & 0 \\
\hline 0,75 & 5,60 & 0,0005 & 0,4 \\
\hline 1 & 4,55 & 0,5965 & 1,2 \\
\hline 1,5 & 7,81 & 0,5945 & 1,2 \\
\hline
\end{tabular}

Tabel 7. Segmen pengamatan nilai kecepatan axial

\begin{tabular}{|c|c|c|c|c|c|c|}
\hline \multirow{2}{*}{ Bil. S } & \multicolumn{6}{|c|}{ Segmen-x yang diamati } \\
\hline & 0,11 & 0,25 & 0,5 & 0,75 & 1 & 1,5 \\
\hline $\mathrm{S}=0$ & 0.932 & 1.854 & 2.719 & 0.411 & 0.157 & 0.130 \\
\hline $\mathrm{S}=0,4$ & 0.888 & 1.443 & 1.244 & 0.593 & -0.668 & -2.041 \\
\hline $\mathrm{S}=0,7$ & 0.796 & 1.201 & 0.692 & 0.035 & -1.821 & -3.362 \\
\hline $\mathrm{S}=1$ & 0.701 & 0.903 & 0.366 & -0.544 & -2.577 & -4.161 \\
\hline $\mathrm{S}=1,2$ & 0.701 & 0.707 & 0.098 & -1.027 & -3.047 & -4.576 \\
\hline
\end{tabular}

\subsection{Kontur nilai kecepatan pada variasi bilangan swirl}

Dari Gambar 9 terlihat bahwa, untuk S = 0 nilai kecepatan yang besar terkonsentrasi pada daerah dekat inlet annulus saja. Dengan peningkatan nilai bilangan S maka konsentrasi pada daerah tersebut makin berkurang, namun 
terdistribusi pada daerah outlet. Hal ini terjadi karena untuk $\mathrm{S}=0$ tidak ada kecepatan inlet yang menyebar kearah tangensial karena nilai kecepatan swirl adalah nol. Oleh karena itu, dengan adanya nilai bilangan swirl pada sisi inlet maka kondisi awal aliran telah memiliki kecepatan dalam arah tangensial.
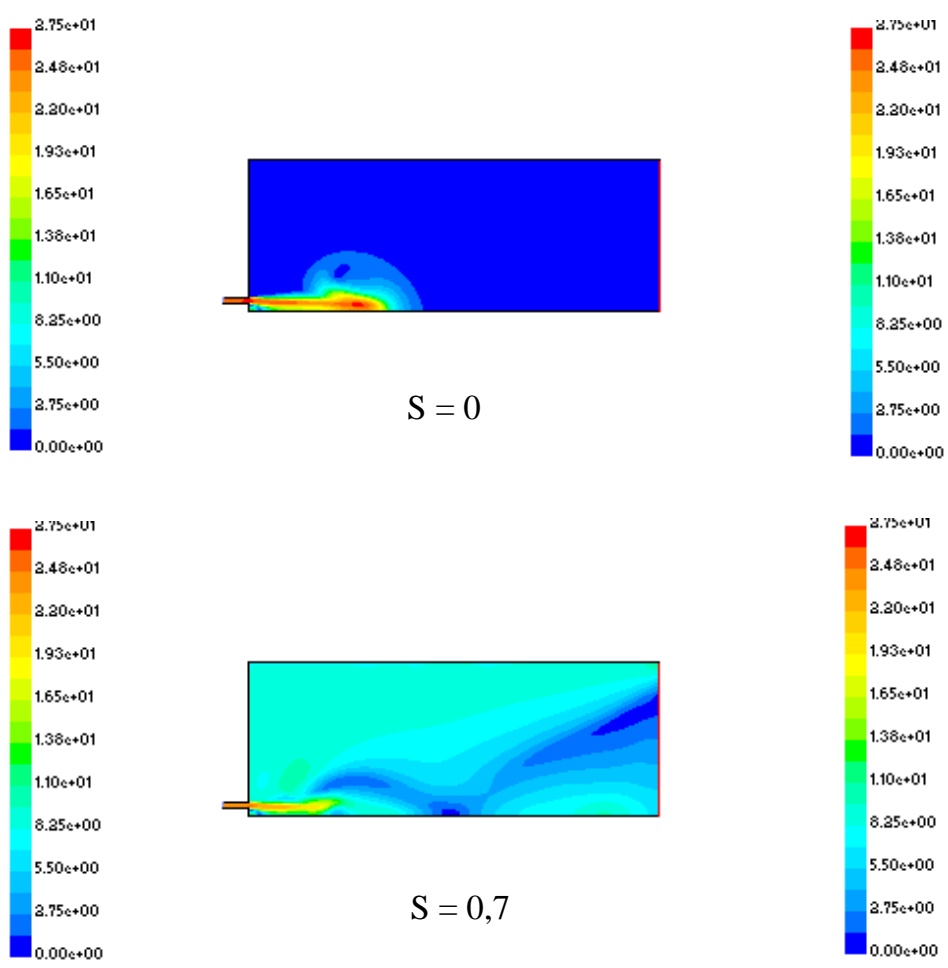



$\mathrm{S}=0,4$

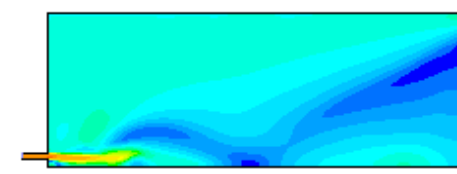

$\mathrm{S}=1,2$

Gambar 9. Kontur nilai kecepatan (magnitude) pada variasi bilangan swirl

\subsection{Nilai kecepatan lokal pada variasi bilangan swirl}

Dari Tabel 8 dapat diamati bahwa pemberian bilangan swirl S yang makin besar akan menyebabkan peningkatan kecepatan axial rata-rata pada setiap segmen yang diamati. Sehingga berdasarkan simulasi yang dilakukan, kecepatan rata-rata maksimum terjadi pada simulasi dengan nilai bilangan $S=1,2$. Hal ini terjadi karena pada penerapan bilangan swirl S pada velocity inlet menyebabkan pola aliran yang terjadi memiliki aliran fluida dengan arah tangensial yang mampu meningkatkan magnitude kecepatan. Adapun pada Tabel 9 ditunjukkan lokasi segmen yang diamati untuk mengetahui nilai kecepatan axial rata-rata tersebut.

Tabel 8. Posisi nilai kecepatan maksimum

\begin{tabular}{|c|c|c|c|}
\hline Posisi x (m) & Kecepatan Maximum (m/s) & Posisi r (m) \\
\hline 0,11 & 27,47 & 0,028 \\
\hline 0,25 & 25,37 & 0,0285 \\
\hline 0,5 & 26,31 & 0 & 0,0205 \\
\hline 0,75 & 18,69 & 0,5425 & 0 \\
\hline 1 & 18,50 & 1,2 & 0,5545 \\
\hline 1,5 & 19,95 & 1,2 & 0 \\
\hline
\end{tabular}

Tabel 9. Segmen yang diamati untuk megetahui nilai kecepatan axial

\begin{tabular}{|c|c|c|c|c|c|c|}
\hline \multirow{2}{*}{ Bil. S } & \multicolumn{6}{|c|}{ Segmen-x yang diamati } \\
\hline & 0,11 & 0,25 & 0,5 & 0,75 & 1 & 1,5 \\
\hline $\mathrm{S}=0$ & 1.671 & 2.086 & 3.539 & 0.578 & 0.169 & 0.130 \\
\hline $\mathrm{S}=0,4$ & 9.568 & 9.860 & 7.697 & 7.198 & 6.819 & 5.405 \\
\hline $\mathrm{S}=0,7$ & 13.306 & 13.186 & 11.714 & 10.373 & 9.693 & 8.057 \\
\hline $\mathrm{S}=1$ & 15.661 & 15.304 & 14.500 & 12.39 & 11.345 & 9.734 \\
\hline $\mathrm{S}=1,2$ & 16.491 & 16.152 & 15.456 & 12.998 & 11.727 & 10.436 \\
\hline
\end{tabular}

\subsection{Kontur intensitas turbulensi pada variasi bilangan swirl}

Pada Gambar 10 ditunjukkan bahwa pada simulasi dengan S = 0, intensitas turbulensi yang terjadi pada area outlet, setelah melalui annulus, terkonsentrasi pada zona di sekitar posisi outlet annulus. Namun pada daerah yang jauh dari outlet annulus, intensitas turbulensi yang terjadi sangat kecil dibandingkan dengan intensitas turbulensi yang terjadi pada daerah tersebut. Sedangkan pada simulasi yang dilakukan dengan memberikan bilangan swirl menunjukkan efek 
peningkatan intensitas turbulensi pada area outlet setelah melalui annulus. Peningkatan intensitas turbulensi ini adalah sebagai akibat dari efek kecepatan aliran swirl yang diterapkan pada pada sisi inlet [4].
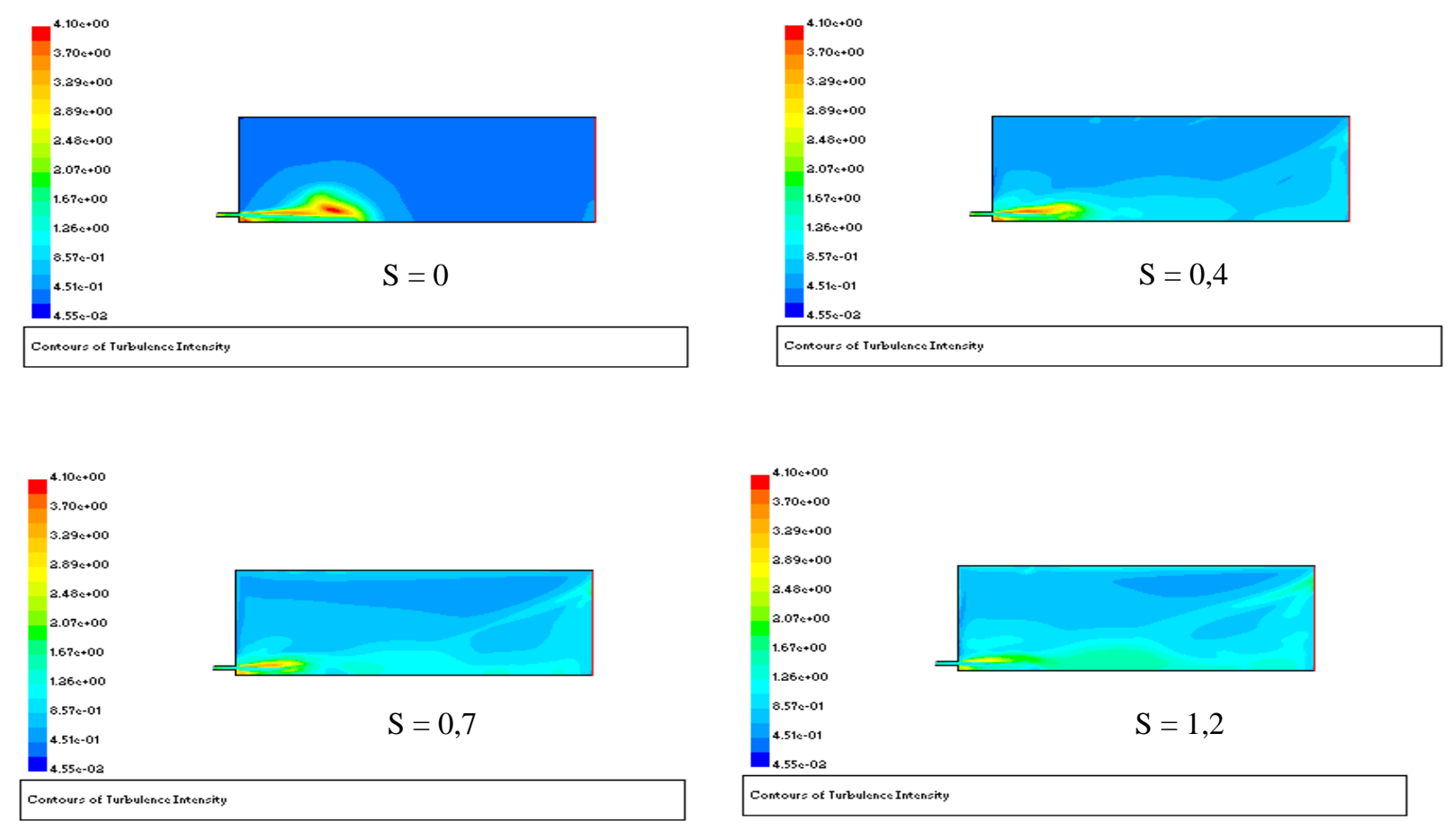

Gambar 10. Kontur intensitas turbulensi pada variasi bilangan swirl

\subsection{Intensitas turbulensi lokal pada variasi bilangan swirl s}

Dari Tabel 10 dapat diketahui bahwa penerapan bilangan swirl S yang makin besar menyebabkan peningkatan intensitas turbulen rata-rata pada daerah yang jauh dari outlet annulus. Pada daerah tersebut juga memiliki karakter pola intensitas turbulen yang makin meningkat dengan meningkatnya bilangan S pada sisi inlet. Dari pengamatan terhadap kontur dan profil intensitas turbulensi lokal dapat diketahui bahwa, dengan menerapkan aliran swirl pada sisi inlet akan meningkatkan nilai intensitas turbulensi, dibandingan dengan tanpa menerapkan aliran swirl. Pada aplikasi sistem pembakaran sebuh motor bakar, kondisi ini dapat dimanfaatkan untuk meningkatkan daya maupun efisiensi pembakaran yang dihasilkan. Hal ini disebabkan karena proses pencampuran antara udara dengan bahan bakar akar lebih efektif akibat adanya komponen kecepatan tangensial yang memiliki intensitas turbulensi yang tinggi [3].

Tabel 10. Posisi intensitas turbulensi maksimum

\begin{tabular}{|c|c|c|c|}
\hline & intensitas turbulensi & Posisi r (m) \\
\hline Posisi x (m) & 3,97 & 0,0505 & 0,0495 \\
\hline 0,11 & 3,84 & 0,4 & 0,4 \\
\hline 0,25 & 3,99 & 0695 & 0,0635 \\
\hline 0,5 & 1,64 & 0,0405 & 0,4 \\
\hline 1,5 & 1,52 & 1,2 & 0,0205 \\
\hline
\end{tabular}

Tabel 11. Segmen yang diamati untuk megetahui nilai kecepatan axial

\begin{tabular}{|c|c|c|c|c|c|c|}
\hline \multirow{2}{*}{ Bil. S } & \multicolumn{6}{|c|}{ Segmen-x yang diamati } \\
\hline & 0,11 & 0,25 & 0,5 & 0,75 & 1 & 1,5 \\
\hline$S=0$ & 0.561 & 0.667 & 0.434 & 0.474 & 0.437 & 0.436 \\
\hline $\mathrm{S}=0,4$ & 0.775 & 0.938 & 1.147 & 0.719 & 0.701 & 0.722 \\
\hline $\mathrm{S}=0,7$ & 0.858 & 0.998 & 0.854 & 0.837 & 0.824 & 0.859 \\
\hline $\mathrm{S}=1$ & 0.891 & 1.029 & 0.796 & 0.942 & 0.917 & 0.948 \\
\hline $\mathrm{S}=1,2$ & 0.890 & 1.016 & 0.949 & 0.986 & 0.943 & 0.979 \\
\hline
\end{tabular}

\section{Kesimpulan}

Berdasarkan hasil penelitian ini dihasilkan kesimpulan umum bahwa untuk mengamati aliran swirling untuk keperluan berbagai aplikasi, dapat dilakukan dengan hasil yang cukup memuaskan dengan menggunakan metoda komputasi numerik. Oleh karena itu, perancangan suatu sistem pembakaran akan menjadi lebih mudah, murah dan cepat dilakukan sebelum melakukan pembuatan protipe dan melakukan uji eksperimental. Selain itu, hasil penelitian ini 
juga dapat digunakan untuk melakukan perancangan alat pembangkit aliran swirling yang ditempatkan pada bagian sebelum masuk ke ruang bakar. Adapun kesimpulan lain yang diperoleh dari penelitian ini diantaranya adalah:

1) Terjadi penurunan kecepatan axial campuran n oktan-udara pada daerah aliran jet dekat outlet annulus dengan penerapan bilangan swirl S yang semakin besar pada velocity inlet.

2) Penerapan bilangan swirl $S$ pada velocity inlet mampu meningkatkan magnitude kecepatan rata-rata campuran $n$ oktan-udara. Dimana dari hasil simulasi diperoleh adanya hubungan penerapan bilangan swirl S yang semakin besar mampu meningkatkan magnitude kecepatan rata-rata pada setiap segmen yang diamati.

3) Kualitas pembakaran bahan bakar dapat ditingkatkan dengan menerapkan aliran swirl pada inlet velocity yang mampu meningkatkan intensitas turbulensi, yang selanjutnya dapat meningkatkan tingkat efisiensi pencampuran bahan bakar dengan udara, sehingga proses pembakaran menjadi lebih baik.

\section{Referensi}

[1] White, Frank M, Fluid Mechanics, $7^{\text {th }}$ ed., McGraw-Hill, New York, 2011.

[2] Round, G F and V.K Garg, Application Of Fluid Dynamics, Edward Arnold Publisher, Ltd.,London, 1986.

[3] Wang, Ping, Large Eddy Simulation of Turbulent Swirling Flows and Turbulent Premixed Combustion, University of Karlsruhe, Germany, 2005

[4] Islek, Akay A., The Impact Of Swirl in Turbulent Pipe, Georgia Institute Of Technology , 2004.

[5] Tutorial FLUENT, Fluent Inc, 2013.

[6] Villalba , M. García and J. Fröhlich Ernest, On The Sensitivity Of A Free Annular Swirling Jet To The Level Of Swirl And A Pilot Jet, University of Karlsruhe, Germany, 2005 